\title{
THE POPULATION LEVEL OF WESTERN CORN ROOTWORM ADULTS IN THE PERIOD 2005-2009
}

\author{
Snežana Gošić-Dondo ${ }^{{ }^{*}}$, Jelena Srdić ${ }^{1}$ Željko Popović ${ }^{2}$ Jan Tancik ${ }^{3}$
}

\begin{abstract}
Western corn rootworm (WCR) (Diabrotica virgifera virgifera LeConte) is one of the most important and potentially most dangerous pests of maize. Since its occurrence in Serbia in 1992, it has been present in almost all areas under maize cultivation. Alongside with all preventive measures, first of all, the crop rotation, which is considered the most economic one, a great attention has been paid to the forecast of the pest occurrence based on the flight dynamics and the population level. The flight dynamics, sex dominance, variations in the population level depending on the trap types and climate factors were observed on two locations: Crepaja in three-year continuous cropping (2005-2007) and in the experimental field of the Maize Research Institute, Zemun Polje in the duration of five years (2005-2009). According to the flight dynamics of WCR adults, the highest population level of this pest was observed in 2005, while the comparison of the number of adults over locations showed greater abundance of the pest in Crepaja than in Zemun Polje, which was attributed to extreme favourability of agro-ecological conditions on this location for the WCR development. The 2008-2009 period was characterised by the reduced number of WCR, which coincided with the extremely arid conditions that do not favour the development of this pest.
\end{abstract}

Key words: Western corn rootworm, population dynamics, climate conditions

\section{Introduction}

Western corn rootworm (D. virgifera virgifera LeConte) is the most destructive insect species in all regions under maize cultivation worldwide. It is believed that $D$. virgifera virgifera and the plant host have been evolved together in subtropical regions of Mexico and Central and Northern America (Meinke et al., 2009). The rapid distribution of WCR and the formation of the continuous population have resulted in intensive attacks, which affected the maize production throughout Europe. The WCR was probably introduced in the second half of the 1970s (Edwards et al., 1994; 1998).

Since the moment of its appearance in Serbia (1992), this polyphagous pest has been populating the main production regions of maize cultivated in continuous cropping and its territorial expansion was faster than the spread of areas of harmfulness/destruction. In a short period of time, this pest has spread in as many as 13 European countries, including Austria, Bosnia and Herzegovina, Bulgaria, Czech Republic, France, Hungary, Italy, Romania, Slovak Republic, Switzerland and Ukraine.

This insect species has one generation per year and overwinters as eggs in soil (diapausing eggs). Larva hatching varies over years, but it is usually performed at the end of May and the beginning of June. Their presence is observable up to the beginning of August, and maximum of their emergence occurs at the end of July and the beginning of August (Komaromi and Kiss, 2004; Pierce and Gray, 2007; Bača et al., 2002; Borzykh et al., 2013; Voineac et al., 2015; Igrc-Balćić et al., 2004). Male adults

Original Scientific Paper (Originalni naučni rad)

${ }^{1}$ Gošić-Dondo S, Srdić J, Maize Research Institute Zemun Polje, Slobodana Bajića 1, Belgrade, Serbia

${ }^{2}$ Popović Ž, Faculty of Sciences, University of Novi Sad, Trg Dositeja Obradovića 2, Novi Sad, Serbia

${ }^{3}$ Tancik J, ORGANIX, s.r.o., Rastislavova 1067/323, 95141 Lužianky - Nitra, Slovakia

*e-mail: sgosic@mrizp.rs 
occur a bit earlier than female adults, because the development of males is faster than the development of females, while the population peak of males (50\%) occurs before a cumulative occurrence of females.

It is generally accepted that the presence of one or more adults per plant at the time of their maximum abundance, can result in economically significant damages by larvae during the following year in fields under maize continuous cultivation. In order to avoid further spread and development of the population, as well as a possibility of economic and ecological impacts, a timely forecast is necessary to regulate the level of the abundance of the insect population of both sexes. The forecast of the intensity of a WCR attack is based on the number of hatched larvae after sowing, the number of captured individuals on yellow and green sticky and pheromone traps. The effectiveness of different trap types is based on their attractiveness for adults, which is reflected in deviations of the population abundance and the sexual index as main parameters of dynamic changes. The differences in the population abundance over years were present on all locations. The maximum number of the population and oviposition did not overlap in all years. The comparison of the total number of adults overall years, locations and trap types showed that the pheromone Pal Csalomon trap, then green Multigard and yellow Pherocon AM sticky traps were the most efficient.

Environmental factors significantly affect the occurrence, development and reproductive ability of WCR. A precipitation sum must be taken into account when forecasting the WCR occurrence. The more frequent precipitation during overwintering of eggs the lower percentage of their destruction. The lack of moisture in the soil significantly reduces the number of WCRs and, consequently, damage to corn is lower (Manole et al., 2017).

The aim of this study was to monitor and manage the WCR population to prevent invasion of this economically damaging insect species. Monitoring requires comprehensive knowledge of biological traits of the pest, its life cycle and the economic threshold of harmfulness so that the response could welltimed and efficient plant protection could be implemented.

\section{Material and Methods}

The WCR flight dynamics was visually monitored by the application of pheromone Csalomon, yellow (Pherocon $\mathrm{AM}^{\circledR}$ ) and green sticky traps (Multigard) in the period from the beginning of July to the end of September.

Visual inspection of plants was based on the determination of the density of insect abundance by counting and expressing the average number per plant. A hundred plants were examined (10 plants sampled in 10 randomly selected spots) during silking (June $25^{\text {th }}$ - July $2^{\text {nd }}$, depending on the location and the year) for 2-3 days. The presence of adults was established on leaves, stalks and ears of maize in early morning hours $\left(7^{30}-8^{30}\right)$, when the activity of adults is greatest since high temperatures do not suit them. The total number of insects was determined in 100 plants in Zemun Polje and Crepaja during the three-year period (2005-2007) in the field crops on corn hybrid ZP 434.

The presence of WCR adults was monitored by yellow (Pherocon $\mathrm{AM}^{\circledast}$ ) and green (Multigard) rectangle traps $(28 \times 22.5 \mathrm{~cm})$, with a sticky surface facing outward when it was wrapped around the maize plant at the ear height. These traps were made of waterproofed cardboard, and applied glue was of exceptional thermal and hydrostatic properties. Traps were set up in early July, and replaced every two weeks, while the trap inspection was done every third day.

At the same time, Pheromone panel Csalomon traps were randomly set at the ear height. These traps had a sexual pheromone as an attractant, stored within the small capsule hanged in the middle of the trap. Individuals attracted by pheromone were glued to a colourless external sticky surface $(36 \times 23 \mathrm{~cm})$ of the trap. Capsules and sticky panels were replaced every 28 and 15 days, respectively. The number of captured females and males was regularly recorded. 


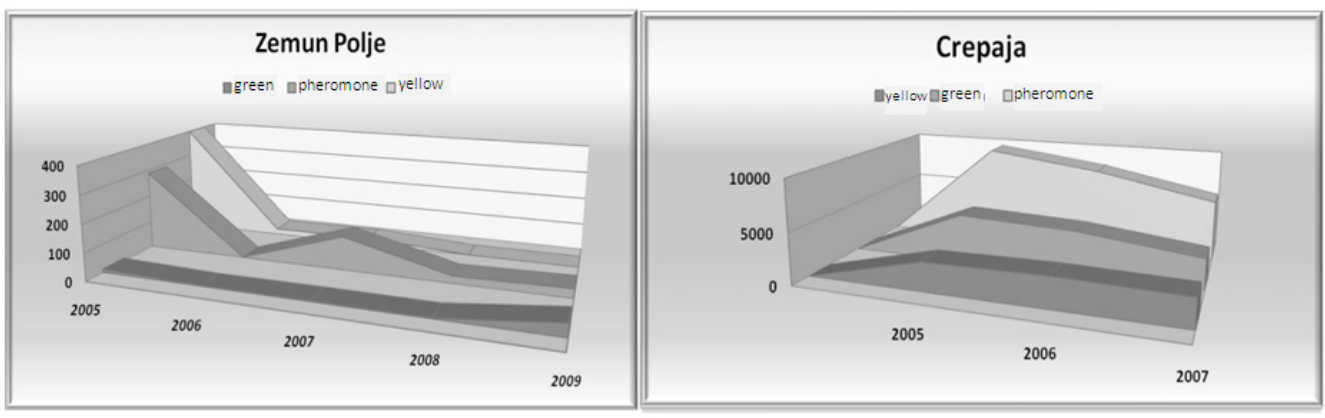

Figure 1. Monitoring adults of western corn rootworm (D. virgifera virgifera) on pheromone, yellow and green sticky traps

Grafikon 1. Monitoring imaga kukuruzne zlatice (D. virgifera virgifera) na feromonskim, žutim i zelenim leplivim klopkama

A total of 45 traps, 15 of each type, were placed during the monitoring season of flight dynamics of WCR adults. In Zemun Polje, traps were inspected 11 times during the fiveyear investigation (from July 10 to August 18). On the other hand, the three-year investigation (2005-2007) was carried out in Crepaja and inspections were performed on the following dates: July 10, 13, 17, 20 and 27 and August 3.

\section{Results and Discussion}

In the investigated period (2005-2007), on two locations, variations in the abundance and density of the adult population of $D$. virgifera virgifera were established by the application of the absolute sampling method. During the stated period, in July, in the period of maize silking, adult insects were detected in analysed locations. Similar results have been recorded in other European countries. WCR adults have been present in the maize growing regions of Poland, Bulgaria, Ukraine and Croatia form the second half of July to the end of September and the beginning of October (Bereš and Sionek, 2010, 2012; Toshova et. al., 2017; Borzykh et al., 2013; Voineac et al., 2015; Igrc-Balćić et al., 2004).

The differences between locations were determined by monitoring the WCR distribution by the application of the visual methods. Out of total 1.007 registered adults, 591 (58.68\%) and $416(41.31 \%)$ were detected on the locations of Crepaja and the experimental field of the Maize Research Institute, Zemun Polje, re- spectively. Based on 100 examined plants, the average number of adults ranged from 1 to 9 . On the location Crepaja, the number of adult insects per plant was 10-12 individuals, or 7-9 insects, on average.

The WCR flight dynamics was monitored using the pheromone, yellow Pherocon AM and green Multigard sticky traps in the period from July $7^{\text {th }}$ to August $18^{\text {th }}$. In Zemun Polje, the maximum abundance of adults was recorded on yellow and pheromone traps in 2005. The drastic drop in the number of adults was noted in 2006, while only pheromone traps were efficient enough to register WCR individuals in 2007. In the succeeding period (2008-2009), the reduction in the abundance of this harmful species was recorded in all three trap types.

Monitoring the abundance of WCR adults in the three-year continuous maize cropping, started by setting traps in Crepaja on July 5, 2005. The high population level of adults in this location was recorded in all three years, particularly in 2005. In the 2005-2007 period, the total of $8,550,12,101$ and 24,028 adults were registered on yellow, green sticky traps and pheromone trap, respectively (Figure 1).

The beginning of the WCR flight was registered in Zemun Polje on July 17th 2005 (Table 1). Out of the total number of registered individuals, there were 240 males and 42 females on pheromone traps, 363 males and 35 females on yellow traps, while only 12 males were captured on the green traps (Figure 2). 


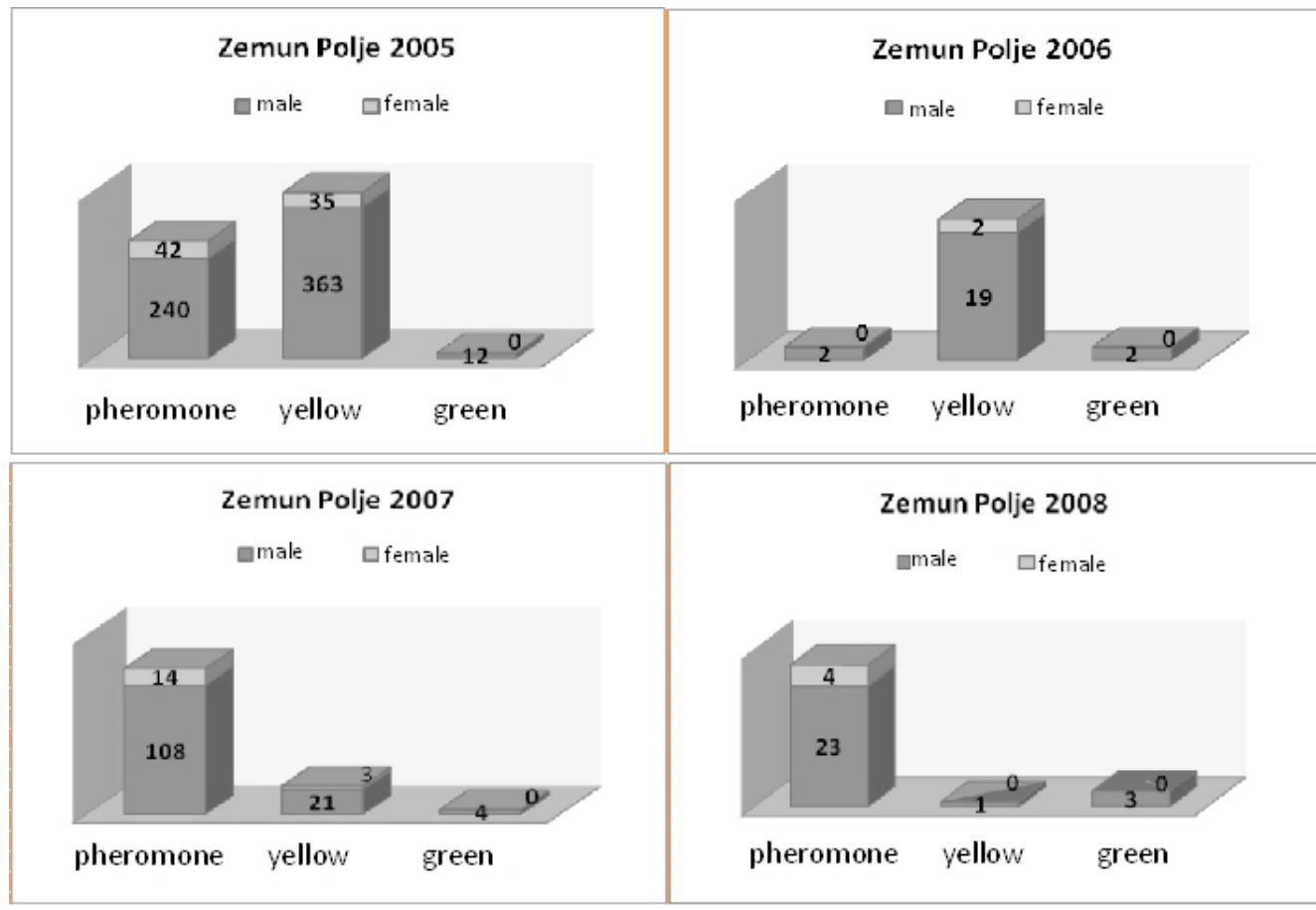

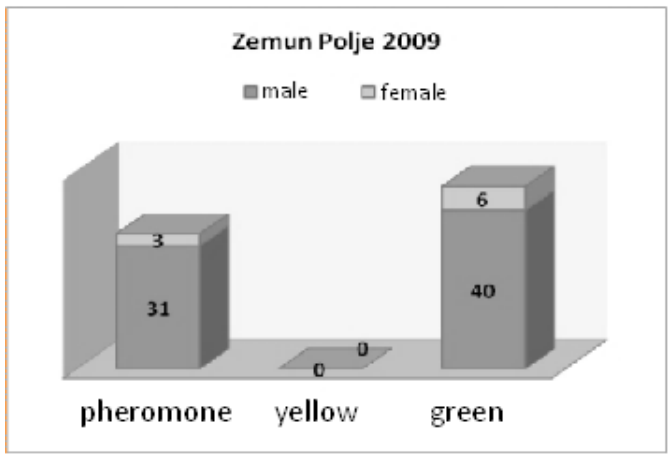

The abundance and dynamics of the WCR population were completely altered in Zemun Polje during 2006 when a low number of adults was recorded in all trap types: only 19 males and two females on yellow traps and two males with no females on pheromone and green traps (Figure 2).

Favourable climatic conditions during 2007, the beginning of the summer on July $10^{\text {th }}$, as well as the presence of adults until the end of the growing season, affected the flight duration. Comparing to the previous year, in Zemun Polje, a significant increase in the number of males and females were observed on pheromone traps.
Figure 2. The abundance of adults of both sexes over years and trap types in Zemun Polje Grafikon 2. Brojnost imaga oba pola po godinama i tipovima klopki u Zemun Polju

The tendency of the decline in the number of adults was observed during 2008 and 2009. Extremely high temperatures during the growing season and low air humidity, alongside with the shortage of high-quality food, resulted in either sporadic catches in August or an absolute absence of flights. The confirmation of our results of an extremely strong impact of climatic conditions on stoppage of the distribution and the reduction in the adult abundance has been provided by the results obtained in other countries infested by this pest. The dry period with a shortened maize growing season can directly affect the population's dynamics (Mahmoud et al., 2017; Manole et al., 2017). According to the 
Table 1. The average number of WCR adults registered on pheromone, yellow and green sticky traps over dates and years in Zemun Polje

Tabela 1. Prosečan broj imaga kukuruzne zlatice registrovan na feromonskim, žutim i zelenim lepljivim klopkama po datumima i godinama očitavanja u Zemun Polju

\begin{tabular}{|c|c|c|c|c|c|c|c|c|c|c|c|c|c|}
\hline \multirow{3}{*}{$\begin{array}{l}\text { Reading. } \\
\text { date }\end{array}$} & \multicolumn{4}{|c|}{ Pheromone Pal } & \multicolumn{4}{|c|}{ Yellow Pherocon AM } & \multicolumn{4}{|c|}{ Green Multigard } & \\
\hline & \multicolumn{13}{|c|}{ Average number of adults } \\
\hline & 2005 & 2006 & 2007 & $\Sigma$ & 2005 & 2006 & 2007 & $\Sigma$ & 2005 & 2006 & 2007 & $\Sigma$ & $\Sigma \Sigma$ \\
\hline July 10 & 0.00 & 0.00 & 1.87 & 28 & 0.07 & 0.07 & 0.00 & 2 & 0.00 & 0.00 & 0.07 & 1 & 31 \\
\hline July 13 & 0.00 & 0.00 & 0.73 & 11 & 1.60 & 0.00 & 0.20 & 27 & 0.40 & 0.00 & 0.00 & 6 & 44 \\
\hline July 17 & 1.20 & 0.00 & 1.33 & 38 & 3.27 & 0.07 & 0.07 & 51 & 0.07 & 0.00 & 0.00 & 1 & 90 \\
\hline July 20 & 1.73 & 0.00 & 1.27 & 45 & 1.67 & 0.33 & 0.00 & 30 & 0.00 & 0.00 & 0.07 & 1 & 76 \\
\hline July 23 & 2.87 & 0.00 & 2.13 & 75 & 2.73 & 0.13 & 0.40 & 49 & 0.00 & 0.00 & 0.13 & 2 & 126 \\
\hline July 27 & 1.73 & 0.00 & 0.00 & 26 & 4.20 & 0.07 & 0.00 & 64 & 0.00 & 0.00 & 0.00 & 0 & 90 \\
\hline August 3 & 0.67 & 0.13 & 0.20 & 15 & 2.60 & 0.53 & 0.67 & 57 & 0.33 & 0.13 & 0.00 & 7 & 79 \\
\hline August 7 & 4.13 & 0.00 & 0.53 & 70 & 3.07 & 0.20 & 0.20 & 52 & 0.00 & 0.00 & 0.00 & 0 & 122 \\
\hline August 11 & 2.60 & 0.00 & 0.07 & 40 & 3.93 & 0.00 & 0.00 & 59 & 0.00 & 0.00 & 0.00 & 0 & 99 \\
\hline August 14 & 1.33 & 0.00 & 0.00 & 17 & 1.47 & 0.00 & 0.00 & 22 & 0.00 & 0.00 & 0.00 & 0 & 39 \\
\hline August 18 & 2.73 & 0.00 & 0.00 & 41 & 2.20 & 0.00 & 0.07 & 30 & 0.00 & 0.00 & 0.00 & 0 & 71 \\
\hline$\Sigma$ & 282 & 2 & 122 & $406^{\mathrm{a}}$ & 398 & 21 & 24 & $443^{\mathrm{a}}$ & 12 & 2 & 4 & $18^{\mathrm{b}}$ & 867 \\
\hline
\end{tabular}

Serbian authors (Sivčev and Galo, 2002; Sivčev, 2004; Sivčev and Tomašev, 1999), an exceptionally dry spell can cause the great mortality of adults. Unfavourable climatic conditions identically affected the distribution and the abundance of WCR in Croatia (Igrc-Barčić and Bažok, 2004). Long-term studies of this phenomenon, distribution and abundance of this pest confirm dominant effects of climatic changes on the reduction of levels of WCR populations (Karić et al., 2010; Grozeet al., 2011; Kereši et al., 2005; Cean, 2005; Borzykh et al., 2013). The oscillation in the number of adults of both sexes was recorded in 2008 and 2009 when their number was enormously low (Figure 2).

In the five-year studies in Zemun Polje, trap readings were done in the period from July 10 to August 18. Out of the total number of registered adults (978), there were 467 or $47.8 \%$ on phero- mone traps, 444 or $45.4 \%$ on yellow sticky traps and just 67 or $6.8 \%$ on green Multigard sticky traps (Tables 1 and 3). The maximum number of insects captured on pheromone traps was recorded on July $23^{\text {rd }}$. Out of the total number of registered adults (467) on this trap type, 4.13 adults per trap were recorded on average, which was a maximum value for the stated period. As far as 2006 is concerned, the flight of adult insects almost completely failed, except on August $3^{\text {rd }}$, where there were 0.13 adults per trap. The average number of adults per plant amounted to 0.739 in 2007.

The total number of captured WCR adults on the Pherocon AM yellow sticky traps varied over years and the maximum abundance was on July 27. The highest number of 4.20 adults per trap on average was observed on the same date in 2005 (Table 1).

Table 2. Average values of registered adults over traps and years

Tabela 2. Prosečne vrednosti registrovanih imaga po klopkama i godinama

\begin{tabular}{llll}
\hline Year $\times$ trap & 2005 & 2006 & 2007 \\
\hline Pheromone & $18.8^{\mathrm{b}}$ & $0.133^{\mathrm{d}}$ & $8.133^{\mathrm{c}}$ \\
Yellow & $26.8^{\mathrm{a}}$ & $1.400^{\mathrm{d}}$ & $1.600^{\mathrm{d}}$ \\
Green & $0.800^{\mathrm{d}}$ & $0.133^{\mathrm{d}}$ & $0.667^{\mathrm{d}}$ \\
\hline
\end{tabular}

* Values designated with the same letter are not statistically different at the 0.05 probability level 
Table 3. Average number of WCR adults registered on pheromone, yellow and green sticky traps over dates and years of reading (2008-2009) in Zemun Polje

Tabela 3. Prosečan broj imaga kukuruzne zlatice registrovan na feromonskim, žutim i zelenim lepljivim klopkama po datumima i godinama očitavanja (2008-2009) u Zemun Polju

\begin{tabular}{|c|c|c|c|c|c|c|c|c|c|c|}
\hline \multirow{3}{*}{$\begin{array}{l}\text { Date of } \\
\text { reading. }\end{array}$} & \multicolumn{3}{|c|}{ Pheromone Pal } & \multicolumn{3}{|c|}{ Yellow Pherocon AM } & \multicolumn{3}{|c|}{ Green Multigard } & \\
\hline & \multicolumn{10}{|c|}{ Average number of adults } \\
\hline & 2008 & 2009 & $\Sigma$ & 2008 & 2009 & $\Sigma$ & 2008 & 2009 & $\Sigma$ & $\Sigma \Sigma$ \\
\hline July 10 & 0.00 & 0.00 & 0 & 0.00 & 0.00 & 0 & 0.00 & 1.07 & 16 & 16 \\
\hline July 13 & 0.00 & 0.00 & 0 & 0.00 & 0.00 & 0 & 0.00 & 0.67 & 10 & 10 \\
\hline July 17 & 0.53 & 0.00 & 8 & 0.00 & 0.00 & 0 & 0.07 & 0.33 & 6 & 14 \\
\hline July 20 & 0.33 & 0.60 & 14 & 0.00 & 0.00 & 0 & 0.07 & 0.13 & 3 & 17 \\
\hline July 23 & 0.40 & 0.60 & 15 & 0.00 & 0.00 & 0 & 0.00 & 0.47 & 7 & 22 \\
\hline July 27 & 0.27 & 0.47 & 11 & 0.07 & 0.00 & 1 & 0.07 & 0.40 & 7 & 19 \\
\hline August 3 & 0.13 & 0.13 & 4 & 0.00 & 0.00 & 0 & 0.00 & 0.00 & 0 & 4 \\
\hline August 7 & 0.13 & 0.27 & 6 & 0.00 & 0.00 & 0 & 0.00 & 0.00 & 0 & 6 \\
\hline August 11 & 0.00 & 0.20 & 3 & 0.00 & 0.00 & 0 & 0.00 & 0.00 & 0 & 3 \\
\hline August 14 & 0.00 & 0.00 & 0 & 0.00 & 0.00 & 0 & 0.00 & 0.00 & 0 & 0 \\
\hline August 18 & 0.00 & 0.00 & 0 & 0.00 & 0.00 & 0 & 0.00 & 0.00 & 0 & 0 \\
\hline$\Sigma$ & 27 & 34 & 61 & 1 & 0 & 1 & 3 & 46 & 49 & 111 \\
\hline
\end{tabular}

The drop in the number of adults in 2008 and 2009 resulted in a very low presence of the population (111 adults or $11.3 \%)$ in relation to the total number of adults registered in the five-year period on all trap types. It is important to emphasise that the efficiency of yellow traps was low in the years with the lowest number of WCR population (Table 3 ).

The analysis of variance for the total number of adults in 2008 and 2009 pointed out to highly significant values for years, trap types and their interactions (Table 4).

Results obtained on the monitoring of WCR flight dynamics in Crepaja are presented in Figure 3. Data obtained on the total number of registered individuals of both sexes on all three trap types in Crepaja in the 2005-2007 period indicate the high abundance and migration of WCR adults during July and August. During the 25-day trap reading in the stated period, a total of 4,679 adults were registered out of which 24,028 or $53.8 \%$ were detected on pheromone traps, 8,550 or $19.1 \%$ on yellow traps and 12,101 or $27.1 \%$ on green sticky traps. The maximum abundance, 9,746 captured adults of both sexes, was registered on the Pheromone Pal trap in 2005, with the average number of 16.7 adults per day. The maximum, daily recorded number of adults per trap in Crepaja was detected on both yellow (4.8) and green (8.1) sticky traps, which was above the critical number limit of 6 to 7 adults per trap for the climatic conditions of the USA (Tollefson, 2007). Karić et al. (2010) monitored

Table 4. Analysis of variance for the total number of adults

Tabela 4. Analiza varijanse ukupnog broja imaga

\begin{tabular}{cc}
\hline Analysis of variance & Sum of squares \\
\hline Year & $26.678^{\star *}$ \\
Trap & $33.600^{\star *}$ \\
Year $\times$ trap & $18.311^{\star *}$ \\
\hline
\end{tabular}




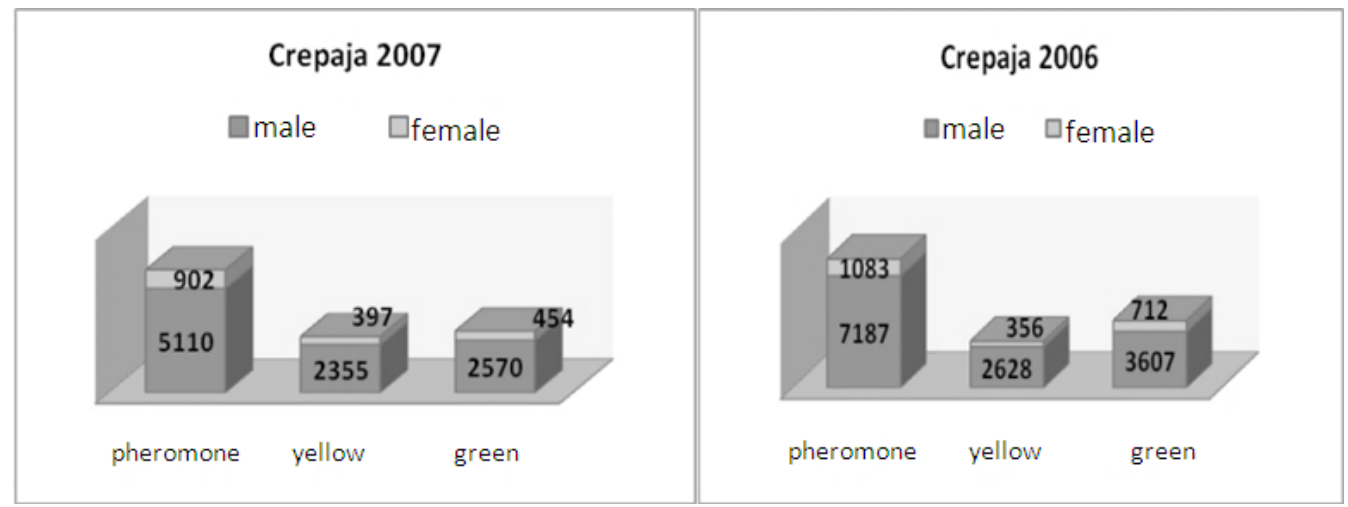

Figure 3. The number of WCR adults over years and trap types in Crepaja

Grafikon 3. Brojnost imaga kukuruzne zlatice po godinama i tipovima klopki u Crepaji

the dynamics of WCR flight in 30 locations in Bosnia and Herzegovina in 2003 and determined the maximum activity of adult insects in the second half of July. In the succeeding years, the highest abundance of captured adults of both sexes was recorded on pheromone traps, but the numbers were lower than in the previous year.

The first reading was performed on July $10^{\text {th }}$ in all three years and the following numbers were recorded: 5,346 (22.2\%), 2,235 (26.1\%) and $1,967(16.3 \%)$ on pheromone, yellow and green traps, respectively. Based on the obtained number it is observable that the highest number of captured adults was detected on pheromone and yellow traps. The total number of captured adults in this period varied over reading dates from 2,324 to 5,346 on pheromone traps, from 732 to 2,235 on yellow traps and from 1,340 to 2,558 on green traps. In the three-year period of investigation, the abundance of adults on pheromone traps was higher by 2.81 and 1.98 than on yellow and green traps, respectively (Table 5).

The analysis of variance of the sum of captured adults showed significance for the following factors: Trap (T), and year (Y), and their interaction $(\mathrm{Y} \times \mathrm{T})$, at almost all reading dates. Significant impact on the total number of adults was established for both factors and their interaction (Table 6).

Table 5. WCR flight dynamics and their average number in Crepaja over trap types, reading dates and years

Tabela 5. Dinamika leta imaga kukuruzne zlatice i njihov prosečan broj u Crepaji po tipovima klop$k i$, datumima i godinama očitavanja

\begin{tabular}{|c|c|c|c|c|c|c|c|c|c|c|c|c|}
\hline & \multicolumn{4}{|c|}{ Pheromone Csalomon trap } & \multirow{2}{*}{\multicolumn{4}{|c|}{$\begin{array}{l}\text { Yellow Pherocon AM trap } \\
\text { Average number of adults }\end{array}$}} & \multicolumn{4}{|c|}{ Green Multigard trap } \\
\hline & \multirow[b]{2}{*}{2005} & \multirow[b]{2}{*}{2006} & \multirow[b]{2}{*}{2007} & \multirow[b]{2}{*}{2} & & & & & & & & \\
\hline & & & & & 2005 & 2006 & 200 & $\Sigma$ & 2005 & 2006 & 2007 & $\Sigma$ \\
\hline & 141.20 & 122.33 & 91.87 & 5346 & 56.87 & 51.68 & 70.47 & 2235 & 50.53 & 48.47 & 32.13 & 1967 \\
\hline July 13 & 111.27 & 93.47 & 59.73 & 3967 & 25.93 & 29.40 & 35.53 & 1383 & 54.00 & 48.60 & 32.53 & 2028 \\
\hline July 17 & 128.00 & 108.07 & 87.80 & 4863 & 36.13 & 34.73 & 32.47 & 1536 & 63.40 & 56.73 & 50.40 & 2558 \\
\hline July 20 & 66.00 & 57.47 & 31.27 & 2324 & 10.80 & 22.60 & 15.40 & 732 & 37.67 & 33.60 & 18.07 & 1340 \\
\hline July 27 & 118.00 & 99.00 & 84.20 & 4519 & 41.93 & 40.30 & 41.80 & 1861 & 61.80 & 55.13 & 39.20 & 2342 \\
\hline August 3 & 85.00 & 70.00 & 45.93 & 3009 & 15.93 & 20.20 & 17.40 & 803 & 49.73 & 45.40 & 29.27 & 1866 \\
\hline$\overline{\mathrm{X}}$ & 649.73 & 551.33 & 400.80 & & 187.60 & 198.93 & 183.07 & & 317.13 & 287.93 & 201.60 & \\
\hline$\Sigma$ & 9746 & 8270 & 6012 & $24028^{a}$ & 2814 & 2984 & 2752 & $8550^{\mathrm{ab}}$ & 4758 & 4319 & 3024 & $12101^{\mathrm{b}}$ \\
\hline
\end{tabular}


Table 6. Analysis of variance of the sum of the registered number of adults in Crepaja over reading dates Tabela 6. Analiza varijanse pribeleženog broja jedinki u Srepaji po datumima očitavanja

\begin{tabular}{rrrrrrrrr}
\hline & & \multicolumn{7}{c}{ MS } \\
\cline { 2 - 8 } & DF & 10.07 & 13.07 & 17.07 & \multicolumn{1}{c}{20.07} & 27.07 & 03.08 & \multicolumn{1}{c}{ Sum } \\
\hline Year & 2 & $9325.9^{*}$ & $5263.1^{*}$ & 4089.9 & $4074.0^{* *}$ & $4006.0^{*}$ & $4499.3^{*}$ & $177960.9^{*}$ \\
Trap & 2 & $78399.2^{* *}$ & $40686.3^{* *}$ & $64092.8^{* *}$ & $14342.2^{* *}$ & $44576.5^{* *}$ & $27047.6^{* *}$ & $1461765.1^{* *}$ \\
Y $\times \mathrm{T}$ & 4 & 1304.8 & $3618.9^{*}$ & $1378.2^{*}$ & $1509.6^{* *}$ & 1176.2 & $1526.2^{*}$ & $56476.3^{*}$ \\
\hline
\end{tabular}

\section{Conclusion}

Based on monitoring of the occurrence and abundance of the WCR population in the fiveyear period (2005-2009), the following can be concluded:

- based on visual inspection of the whole maize plant during the stated period the number of WCR ranged from 1 to 9 per plant;

- the number of adults registered during the three-year period in Crepaja (591) was greater than the number (416) registered in Zemun Polje;

- the highest level of this pest population established by the monitoring of WCR adult flights in two locations (Crepaja and Zemun Polje) during three years and with three trap types was established in 2005;

- the number of adults dropped in the succeeding period (2006-2007) and it continued dropping in 2008 and 2009;

- the beginning of adult flight varied in dependence on the year and the location;

- monitoring of the number of adults over locations show a significantly higher abundance in Crepaja than in Zemun Polje, which was attributed to the agro-ecological conditions in this location that were extremely favourable for the WCR development;

- monitoring of the total number of adults in all years and locations, overall trap types, indicates that pheromone Pal Csalomon traps were most efficient and followed by green Multigard sticky traps, and the yellow Pherocon AM sticky traps.

\section{Acknowledgement}

Results of this research are part of the project: "Integrated system of field crops cultivation: conservation of biodiversity and soil fertility" (TR 31037), supported by the Ministry of Education, Science and Technological Development of the Republic of Serbia.

\section{References}

Bača F, Almaši R, Čamprag D, Sekulić R (2002): Štetočine kukuruza i njihovo suzbijanje. Bolesti, štetočine i korovi kukuruza i njihovo suzbijanje, Novi Sad.

Bereś P K, Sionek R (2010): The occurrence and sex ratio Table 1. of Diabrotica virgifera Le Conte beetles on sweet maize (Zea mays var. saccharata) in south-eastern Poland near Rzeszów in 2007-2009. Vegetable Crop Research Bulletin, 73: 87-97.

Bereś P K, Sionek R(2012): Catches of Western corn rootworm (Diabrotica virgifera Le Conte) beetles by pheromone traps type PAL and feeding traps type PALs in Krzeczowice in 2009-2011. Post.Ochr. Roślin [Progress in Plant Protection], 52 (1): 14-19.

Borzykh O. I, Skrypntk N. V, Filatova N. K, Zhyiboroda O. V(2013): Monitoring of western corn beetle (Diabrotica virgifera virgifera LeConte) in Central Ukraine. Karantin i zahist roslin [Quarantine and Plant Protection], 12: 17-20.

Cean M, (2005): Monitoring of Diabrotica virgifera virgifera Le Conte in Romania in 2004.: Diabrotica Subgroup Meeting (XI) and EPPO ad hoc Panel (X), February, 1417, Bratislava, Slovak Republic, Abstract No. 12.

Edwards C.R, Larry W.B, Turpin F.T (1994): Field crop insects managing corn rootworms 1994. Purdue Universuty, Coopera- 
tive exrtension Service, E-49, 1-6, West Lafayette.

Edwards C.R, Igrc-Barčić J, Berberović H, Berger H.K, Festić H, Kiss J, Princzinger G, Schulten G, Vonica I (1998): Overiew of the FAO Western Corn rootworm managment program for Central Europe. Pflanzenchutzberichte, 57 (2): 34 .

Grozea I. Cărăbeţ A. Ştef R. Vîrteiu A. M, Chis C, Dinnesen S(2011): Analysis of correlations between WCR adults recorded at different altitudes and climate factors. Research Journal of Agricultural Science, 43 (2): 4451.

Igrc-Barčić J, Bažok R (2004): Current status and results of the monitoring of Western Corn Rootworm in 2003 in Croatia: Diabrotica Subgroup Meeting, (X) and EPPO ad hoc Panel, (IX), January, 14-16, Engelberg, Switzerland, Abstract No 4.

Karić N, Festić H, Trkulja V, Majdančić V(2010): Pojava, proširenost i brojnost populacije zlatice kukuruza (Diabrotica virgifera virgifera Le Conte) u Bosni i Hercegovini (19962005). Biljni lekar, str. 103-119.

Kereši T, Sekulić R, Stamenković S, Štrbac P (2005): Važnije štetocine ratarskih biljaka u Vojvodini- pojava u 2004.i prognoza pojave u 2005. godini. Biljni lekar, Vol.XXXIII (1): 25-35.

Komáromi J, Kiss J (2004): Risk Assessment for Western Corn Rootworm. Country report for Hungary. GTFS/RER/017/ITA FAO project report.

Manole T, Chireceanu C, Teodoru A (2017): The broadening of distribution of the invasive species Diabrotica virgifera virgifera LeConte in the area of Muntenia region under specific climatic and trophic conditions. Series A. Agronomy, Vol. LX: 495-499.

Pierce C.M.F,Gray M.E (2007): Population dynamics of a western corn rootworm (Coleoptera: Chrysomelidae) variant in east central Illinois commercial maize and soybean fields. Journal of Ecomomic Entomology, 100: 1104-1115.

Sivčev I (2004): Rasprostranjenost, brojnost i štetnost kukuruzove zlatice (Diabrotica virgifera virgifera Le Conte) u Srbiji 2003. godine. Biljni lekar, Vol. XXX (6): 445453.

Sivčev I, Galo A (2002): Status of Diabrotica virgifera virgifera Le Conte in Serbia in 2002. IX IWGO Diabrotica Subgroup Meeting and VIII EPPO and hoc Panel. November 2-5, 2002. Belgrade, Serbia. Abstract No. 13. Toshova T, Velchev D,. Abaev V, Subchev M, Atanasova D, Tóth M (2017): Detection and Monitoring of Diabrotica virgifera virgifera LeConte, 1868 (Coleoptera: Chrysomelidae) by KLP+ Traps with Dual (Pheromone and Floral) Lures in Bulgaria, Acta zool. bulg., Suppl. 9: 247-254.

Tollefson J.J (2007): Evaluating maize for resistance to Diabrotica virgifera virgifera Le Conte (Coleoptera: Chrysomelidae). Maydica, 52: 311-318.

Mahmoud M. A. B, Sharp R.E, Oliver M. J, Finke D. L, Bohn M, Ellersieck M. R, Hibbard, B. E (2018): Response of maize hybrids with and without rootworm- and drought-Tolerance to rootworm infestation under well-Watered and drought conditions. Journal of Economic Entomology, 111(1): 193-208. DOI: 10.1093/jee/tox309.

Meinke L.J, Sappington T.W, Onstad D.W (2009): Western corn rootworm (Diabrotica virgifera virgifera LeConte) population dynamics. Agricultural and Forest Entomology. 11(1): 29-46.

Manole T,Chireceanu C, Teodoru A (2017):The broadening of distribution of the invasive species Diabrotica virgifera virgifera Leconte in the area of Muntenia region under specific climatic and trophic conditions.Scientific Papers. Series A. Agronomy, Vol. LX: 495-499.

Voineac V, Elisovetcaia D, Cristman D, Babidorici M, Tulgara E (2015): The results of pheromone monitoring of invasive pest Diabrotica virgifera virgifera LeConte in Transcarpathian region of Ukraine. Lucrări Ştiinţifice, Seria Agronomie, 58 (1): 75-78. 


\title{
POPULACIONI NIVO IMAGA KUKURUZNE ZLATICE U PERIODU OD 2005-2009 GODINE
}

\author{
Snežana Gošić-Dondo, Jelena Srdić, Željko Popović, Jan Tancik
}

\begin{abstract}
Sažetak
Pojava Diabrotica virgifera virgifera LeConte na teritoriji Srbije od 1992. godine, rezultirala je masovnim razmnožavanjem i brzim teritorijalnim širenjem. Brojnost populacije je povećavana iz godine u godinu, naročito u područjima gde je kukuruz gajen u monokulturi i dostizala je kritične vrednosti pri kojima nastaju ekonomske štete. Plodored i variranje klimatskih faktora značajno su uticali na pad brojnosti i ostale parametre dinamike populacije.

Cilj istraživanja je bio da se formuliše strategija kojom bi se ostvarila ekološki racionalna kontrola kukuruzne zlatice, zasnovana na prognozi pojave i praćenju brojnosti imaga oba pola, u korelaciji sa klimatskim uslovima i sistemom gajenja kukuruza. Dinamika leta kukuruzne zlatice praćena je vizuelnom metodom, primenom feromonskih Csalomon, žutih (Pherocon AM ${ }^{\circledR}$ ) i zelenih lepljivih klopki tipa Multigard, u periodu od početka jula do kraja septembra. Klopke su postavljane početkom jula, na biljke kukuruza iznad klipa, menjane su svake dve nedelje, a pregled klopki vršen je svaki treći dan.

Dobijeni rezultati su ukazali na dominantan uticaj klimatskih prilika na ispitivane parametre. Razlike u brojnosti populacije uočene su na različitim tipovima klopki, godinama posmatranja i lokalitetima.

Vizuelnim pregledom biljaka uočena su variranja u brojnosti imaga između lokaliteta i godina. Od ukupno 1.007 registrovanih imaga, 58,68\% konstatovano je na području Crepaje i 41,33\% u oglednom polju Instituta za kukuruz Zemun Polje.

Od ukupno registrovanih 867 imaga u Zemun Polju u periodu od 2005-2007godine, na feromonskim klopkama bilo je 406 ili 46,8\%, na žutim lepljivim 443 ili 51,09\% i na zelenim lepljivim, Multigard klopkama, svega 18 ili 2,07\%. Visok nivo populacije imaga za period od tri godine zabeležen je u Crepaji. Na žutoj lepljivoj klopci registrovano je 8.550 imaga, na zelenoj 12.101, a maksimum brojnosti po godini od 24.028 jedinki detektovan je na feromonskoj klopki. U narednom periodu, tokom 2008-2009 godine, ekstremno visoke temperature tokom vegetacije i niska relativna vlažnost vazduha, zajedno sa nedostatkom kvalitetne hrane, rezultirali su sporadičnim ulovima tokom avgusta do potpunog izostanka leta.
\end{abstract}

Ključne riječi: zlatica kukuruza, dinamika populacije, klimatske prilike

Primljen: 2.10.2018.

Prihvaćen: 27.11.2018. 